 \\ International Journal of Social Sciences and Management
}

\section{A Rapid Publishing Journal}

ISSN 2091-2986

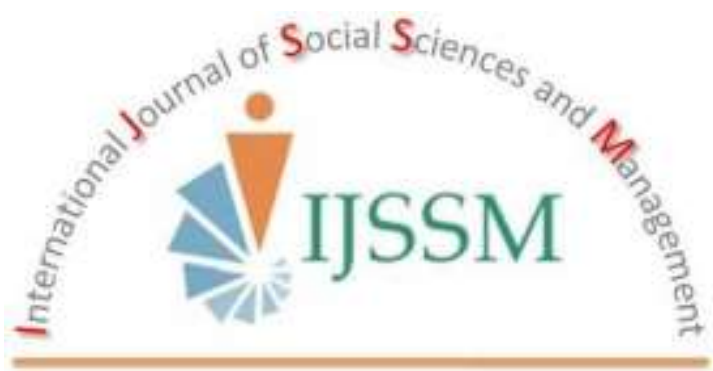

\section{Indexing and Abstracting}

CrossRef, Google Scholar, International Society of Universal Research in Sciences (EyeSource), Journal TOCs, New Jour, Scientific Indexing Services, InfoBase Index, Open Academic Journals Index (OAJI), Scholarsteer, Jour Informatics, Directory of Research Journals Indexing (DRJI), International Society for Research Activity (ISRA): Journal Impact Factor (JIF), Simon Fraser University Library, etc.

Vol-2(1) January, 2015 


\title{
STUDY HABITS OF SECONDARY SCHOOL STUDENTS IN RELATION TO THEIR SOCIO-ECONOMIC STATUS AND GENDER
}

\author{
B. Razia \\ Department of Education, Aligarh Muslim University, Aligarh, U P, India \\ Email for correspondence: razianaushad.amu@gmail.com
}

\begin{abstract}
The study aims to explore the relationship of study habits with socio-economic status and gender. The research was carried out on a sample of 224 students studying in class IX of Aligarh district. Standardized scales were used to collect the data which in turn was analyzed by applying Mean (M), Standard Deviation (SD), Product moment correlation (r), t-test and ANOVA. Findings revealed that significant difference exists in the study habits of students in relation to gender. Significant and positive relationship exists between study habits and Socio-economic status but interaction effect of gender and SES was not found on study habits. Finally the study puts forth some suggestions to enhance the study habits of secondary school students.
\end{abstract}

Keywords: Study habits, Socio-economic status, Gender, Academic achievement, Secondary school students.

\section{Introduction}

Study habits of students, being one of the important correlate of academic achievement are influenced by various factors such as personality traits, motivation, interest and attitude of the learner, parental Socio-economic status, curriculum planning moreover teaching methods adopted also has an important effect on Study habits. Study habits of students are their responses to the requirements or standards set for them by academic institutions. According to Crede and Kuncel (2008) "Study habits are study routines, including but not restricted to, frequency of studying sessions, review of material, self-testing, rehearsal of learned material, and studying in a conducive environment". Some students with high scholastic abilities perform poorly in examinations while others with average abilities often do well. Such unpredictable occurrences have been found to be intimately connected with study habits and skills. Each learner is unique with different abilities, interests, way of thinking and responding thus these characteristics have a significant influence on study habits. Individual differences can be analyzed in terms of control focus, gender, success dimensions etc

Socioeconomic status (SES) is one of the most widely used contextual variable in educational research which is often used to find its impact and correlation with academic achievement. The term Socio-economic status means the background or standing of one or more persons in the society on the basis both of social class and financial situation. Socioeconomic status refers to as a finely graded hierarchy of social positions which can be used to illustrate a person's overall social position or reputation. It can be indicated by a number of sub concepts such as employment status, occupational status, educational attainment and income and wealth (Graetz, 1995). The socioeconomic status of a child is usually determined by parental educational level, parental occupational status and income level (Jeynes, 2002).

The investigator has selected Socio-economic status and gender as independent variables for the present study.

\section{Literature Review}

The role of Study habits in academic achievement of students has been studied repeatedly during the past five decades. Laxminarayanan et al. (2006) and Sarwar et al. (2009) found that overachievers possessed better study habits than underachievers while Sirohi (2004) concluded that poor study habits were one of the main causes for underachievement. Lidhoo and Khan (1990) observed that poor study habits and low need-achievement were associated with underachievement among bright subjects. Aisha R et al. (2002) conducted a study aimed at determining the effect of study habits on the achievements of students and observed that significant and positive relationship exists between achievement and a proper study schedule while Fielden (2004) asserted that good study habits help the students in critical reflection in skills outcomes such as selecting, analyzing, critiquing, and 
synthesizing while Perveen (2011) examined that counseling play an important role in improving study habits of students. When the differences were examined in terms of gender, Pillai (2012) observed that significant difference exists in the study habits of male and female students moreover research studies revealed that female students were more successful academically than their male counterparts and they have better study habits and attitudes (Tinklin, 2003; Hong and Lee, 2000; Anton and Angel, 2004; Houtte, 2004; Sud and Sujatha, 2006)

It is globally suggested that social-economic status is the key factor in academic performance, Caldas and Bankston 1997; Alam 2006 found that Socio-economic status is significantly related with students' academic achievement and Suleman et al. (2013) in his study concluded that parental Socio-economic status; their educational, occupational and income level affects the academic achievement of students at secondary level. Sirin (2005) conducted a meta-analytic review of research on SES and academic achievement in journal articles published between 1990 and 2000. The results showed a medium to strong SES-achievement relation. This relation was moderated by the unit, the source, the range of SES variable, and the type of SES-achievement measure.

It is clear from the review of related studies that study habits and SES are strong correlates of academic achievement but none of these studies give a picture of the relation of study habits with SES and gender. In the light of research gaps found, the investigator was desirous to explore the relationship of study habits in relation to SES and gender.

\section{Objectives of the Study}

The present study has following Objectives

I. To examine the study habits of secondary school students in secondary schools of Aligarh city.

II. To ascertain the study habits and socio-economic status of male and female students of secondary schools.

III. To examine the relationship between study habits and socio-economic status of students.

IV. To assess the impact of gender and socioeconomic status on study habits of secondary school students.

V. To examine the main and interaction effects of socio-economic status and gender on study habits.

\section{Hypotheses}

Following Null hypotheses were developed for the study

i. Male and female Students of Secondary schools do not differ significantly in their study habits.

ii. There will be no significant relationship between study habits and socio-economic status of secondary school students.

iii. There will be no significant difference in the study habits of male and female Students belonging to different Socio-economic status level. iv. There will be no significant main and interaction effect of socio-economic status and gender on study habits.

\section{Delimitations of the Study}

i. The study was confined to 5 schools only.

ii. Only the students of class IX were selected as the sample in this study.

iii. Only 224 students (female and male) were identified for the present investigation.

iv. The study was restricted to the variables SES and Gender as related to study habits, though there are other correlates to study habits.

\section{Method}

The study is descriptive in nature. The researcher has adopted survey method. The school survey is a comprehensive study of existing conditions of schools and suggests improvement wherever necessary.

\section{Population and Sample}

Population of the present study includes all the students studying at secondary school level in the Aligarh district of U.P. India. The sample extracted out of this population consists of a total number of 224 students studying in class IX from 5 secondary schools of Aligarh city using incidental sampling technique. 114 students were males and 110 students were females.

\section{Tools used in the Study}

In order to meet the needs and objectives of the study, following tools were adopted.

\section{Study Habits Inventory developed by Patel B V and Socio-economic status scale by Srivastava G.P.}

i. $\quad$ Study Habit Inventory Scale (SHI): Study Habits Inventory Scale, constructed and validated by B.V Patel consists of 45 statements, 27 statements depicting good study habits and 18 statements depicting poor study habits. Each statement has 5 options. 'Always' 'Often' 'Sometime' 'Rarely' and 'Never'. The statements fall into seven dimensions. The reliability of the tool as given by the author determined by test- retest method was .79 and split half method was .82 respectively. The validity had been established by using external criteria and was found to be .82 . Intrinsic validity was found to be 0.85 .

Statements fall under Home environment and planning of work; Reading and note taking; Planning of subject; Habits of concentration; Preparation for examination;

General habits and attitudes and School environment.

ii. Socio-economic status scale (SES): The original SES scale of Srivastava, slightly modified and further standardized by Sharma (2009) for research work was used for the present study. The 
modified scale included items regarding mother's education, income and social participation which was lacking in the original scale. The scale consists of 10 items representing the various aspects of SES. According to the author the reliability of the scale was found to be 0.92 as determined by testretest method. It possesses content validity. Concurrent validity was established by testing identifiable groups. Construct validity was tested by applying the test of normal probability.

\section{Collection of Data}

The investigator personally visited the schools after obtaining permission from respective principals, where students were contacted and explained about the purpose of the study. Students were instructed how to respond to different tools and the tools of study habits inventory and SES were administered to the students. In order to develop rapport and get right responses from the respondents a brief talk was given to them. The instructions given in each tool were explained in a specified manner and it was ensured that students did not have a chance to talk to other students or glance at their answers. Clarifications were offered on the doubts raised by the students. Each tool was administered in accordance with the instructions laid down in their respective manuals.

\section{Statistical Techniques used}

Mean (M), Standard Deviation (SD), Product moment correlation (r), t-test and Analysis of variance (ANOVA) were employed for analysis of the data.

\section{Analysis and Interpretation of the data}

\section{Study of total score distribution}

It is evident from the Table 1 that total no of students were 224 and their mean study habit score was 162.71 with S D $=18.04$ the mean score lies between 160 and 179 score limits which fall in the category of normal study habits. This indicates that study habits of secondary school students were satisfactory.

Table 1: Distribution of total study Habit Scores

\begin{tabular}{|l|l|l|}
\hline Number of students & Mean & S D \\
\hline 224 & 162.71 & 18.04 \\
\hline
\end{tabular}

Study of score distribution for male and female students.

It is evident from the Table 2 that total number of male students were 114 and 110 were female students. The mean study habit score of male students was 159.02 with $\mathrm{SD}=17.94$ and mean study habit scores of female students was 166.54 with $\mathrm{SD}=17.25$.
Table 2: Distribution of Study Habit Scores with respect to gender

\begin{tabular}{|l|l|l|l|}
\hline Students & N & MEAN & SD \\
\hline Male & 114 & 159.02 & 17.94 \\
\hline Female & 110 & 166.54 & 17.25 \\
\hline
\end{tabular}

Study of score distribution of socio-economic status of male and female students

It is revealed from the Table 3 that mean SES score of male students was 59.11 with $\mathrm{SD}=28.47$ and mean SES score of female students was 71.39 with $\mathrm{SD}=23.49$ indicating that female students were having high socio-economic status than males.

Table 3: Distribution of Socio-Economic Status Scores

\begin{tabular}{|l|l|l|l|}
\hline Students & N & MEAN & SD \\
\hline Male & 114 & 59.11 & 28.47 \\
\hline Female & 110 & 71.39 & 23.49 \\
\hline
\end{tabular}

Study of the relationship between study habits and Socioeconomic status

Product moment correlation was applied to examine the relationship between study habits and Socio-economic status. The correlation values is given in the Table 4

Table 4: Relationship between study habits and Socioeconomic status

\begin{tabular}{|l|l|l|l|l|l|}
\hline $\mathbf{N}$ & $\overline{\mathbf{X}}$ & $\overline{\mathbf{Y}}$ & $\mathbf{S X}$ & SY & r value \\
\hline 224 & 162.71 & 65.14 & 18.03 & 26.85 & $0.36^{* *}$ \\
\hline
\end{tabular}

It is evident from Table 4 that a significant and positive relationship exists between study habits and Socioeconomic status $(\mathrm{r}=0.36)$ and it was significant at .01 level and hence null hypothesis was rejected.

\section{Study of score distribution for different SES groups}

1. It is evident from the Table 5 that the number of male students belonging to high SES were 15 and high SES female students were 13 . The mean study habit score of High SES male students was 163.33 with $\mathrm{SD}=16.81$ and the mean study habit score of high SES female students was 172.54 with $\mathrm{SD}=14.73$

2. It is evident from the Table 5 that total number of middle SES male students were 49 and their mean study habit score was 159.33 with $\mathrm{SD}=18.74$. Similarly there were 67 middle SES female students in the study with mean of 168.81 and with $\mathrm{SD}=17.96$.

3. The Table 5 also points out that the number of male students belonging to low SES in the present study were 50 and their mean study habit score was 157.42 with $\mathrm{SD}=17.25$ and the number of low SES female is 30 with mean study habit score of 158.87 and $\mathrm{SD}=13.84$ 
Table 5: Mean scores of study habits for different SES groups

\begin{tabular}{|l|l|l|l|l|l|l|l|l|l|}
\hline \multicolumn{1}{|c|}{ Students } & \multicolumn{3}{|c|}{ High SES } & \multicolumn{3}{c|}{ Middle SES } & \multicolumn{3}{c|}{ Sow SES } \\
\hline & $\mathrm{N}$ & Mean & SD & N & Mean & SD & N & Mean & SD \\
\hline Male & 15 & 163.33 & 16.81 & 49 & 159.33 & 18.74 & 50 & 157.42 & 17.25 \\
\hline Female & 13 & 172.54 & 14.73 & 67 & 168.81 & 17.96 & 30 & 158.87 & 13.84 \\
\hline
\end{tabular}

Table 6: Summary of the complete ANOVA in a $3 * 2$ factorial analysis

\begin{tabular}{|c|c|c|c|c|}
\hline Source of Variance & Sum of Squares & Df & Mean Square & $\mathbf{F}$ \\
\hline Total & 72840.14 & 223 & 326.64 & - \\
\hline Between groups & 6154.61 & 5 & 1230.922 & - \\
\hline Within groups & 66685.53 & 218 & 305.90 & - \\
\hline $\mathrm{A}(\mathrm{SSses})$ & 2982.13 & 2 & 1491.07 & $4.87 * *$ \\
\hline $\mathrm{B}(\mathrm{SSg})$ & 3164.82 & 1 & 3164.82 & $10.35 * *$ \\
\hline $\mathrm{AxB}$ & 7.66 & 2 & 3.83 & 0.013 \\
\hline Error within groups & 66685.53 & 218 & & \\
\hline Total & 72840.14 & 223 & & \\
\hline
\end{tabular}

** Significant at 0.01 level

\section{Study of main and interaction effect of socio-economic status and gender on study habits}

In order to examine the main and interactive effects of gender and SES on study habits, analysis of variance (ANOVA) technique was used. The results are given in Table 6.

It is evident from the Table 6 that $F$ ratio between different socio-economic status groups with respect to study habits was 4.87 which was significant at 0.01 level hence null hypothesis was rejected, indicating that students among different SES groups differ in their study habits.

Tabulated $\mathrm{F}$ ratio between the genders in relation to study habits was 10.35 which was significant at 0.01 level hence null Hypothesis was rejected indicating that gender makes a difference in relation to study habits.

$\mathrm{F}$ ratio for socio-economic status and gender interaction on study habits was 0.013 which was insignificant at 0.05 level hence null hypothesis was accepted pointing out that, there was no interactive effect of SES and gender on study habits. Since significant difference was found at 2 stages the data analysis was proceeded further to find out exact where the significance lies.

$t$ test was further employed to find out the significance of difference between means.

\section{Difference in study habits among different SES groups.}

\section{A) Study habits of high SES and middle SES students}

It is evident from the Table 6.1, that total number of High SES students' are 28 and total number of middle SES students were 116. High SES students were having a mean score of 167.61 with $\mathrm{SD}=16.49$ and middle SES students had a mean score of 164.80 with $\mathrm{SD}=13.2$

Table 6.1: mean study habits scores of high SE\$ and middle SES students

\begin{tabular}{|lc|c|c|l|l|}
\hline Group & & N & Mean & SD & t value \\
\hline $\begin{array}{l}\text { High } \\
\text { Students }\end{array}$ & SES & 28 & 167.61 & 16.49 & 1.80 \\
\cline { 1 - 1 } $\begin{array}{l}\text { Middle SES } \\
\text { Students }\end{array}$ & 116 & 164.80 & 13.21 & \\
\hline
\end{tabular}

Insignificant at 0.05 level

The computed $t$ value was 1.80 which was insignificant at 0.05 level. This indicates that High SES students and middle SES students do not differ in their study habits and hence null hypothesis was accepted.

\section{B) Study habits of middle SES students and Low SES students}

Table 6.2: Mean study Habit scores of Middle SES and Low SES students

\begin{tabular}{|l|l|l|l|l|}
\hline Group & N & Mean & SD & t value \\
\hline Middle SES students & 116 & 164.80 & 13.21 & \multirow{2}{*}{$3.24 *$} \\
\hline Low SES students & 80 & 157.96 & 16.10 & \\
\hline * Significant at 0.05 level
\end{tabular}

It is revealed from the above Table 6.2 that number of middle SES students were 116 and their mean study habit score was 164.80 with $\mathrm{SD}=13.21$, similarly number of low SES students were 80 and their mean study habit score was 157.96 with $\mathrm{SD}=16.10$

Computed $t$ value was 3.24 which was significant at 0.05 level and hence null hypothesis was rejected indicating that 
middle SES students and low SES students differ in their study habits.

\section{C) Difference in Study Habits of High SES and low SES students.}

It is evident from the Table 6.3 that total number of High SES students were 28 and their mean study habit score was 167.61 with $\mathrm{SD}=16.49$, similarly number of low SES students were 80 and their mean study habit score was 157.96 with $\mathrm{SD}=16.10$

The calculated $t$ value was 2.70 which was significant at 0.05 level hence null hypothesis was rejected proving that there was a significant difference in study habits of High SES and low SES students.

Table 6.3: Mean Study Habit scores of high SES and Low SES students

\begin{tabular}{|l|l|l|l|l|}
\hline Group & N & Mean & SD & t value* \\
\hline High SES students & 28 & 167.61 & 16.49 & \multirow{2}{*}{2.70} \\
\hline Low SES students & 80 & 157.96 & 16.10 & \\
\hline * Significant at 0.05 level
\end{tabular}

\section{Discussion}

By analyzing the data it was found that students had satisfactory study habits, male and female students differ in their study habits supported by the findings of Pillai (2012). Female students had higher study habits scores than male students and it was similar with the findings of Hong and Lee, 2000; Tinklin, 2003; Anton and Angel, 2004; Houtte, 2004; Sud and Sujatha 2006. Further from data analysis it came into light that a significant relation exists between Study habits and Socio-economic status of secondary school students.

It was found that male and female students differ in their SES, especially female students had higher SES than male students. Female students had better study habits than their male counterparts in all the three (High, Middle and Low) SES groups however interaction effect of gender and SES was not found on the study habits of students. Further High SES students had better study habits than Low SES students and so also Middle SES students proved better in comparison to Low SES students.

\section{Educational implications}

It is clear from the study that study habits of students are linked with their socio-economic status and gender. Higher the SES of students better is their study habits. Since the students from low SES have poor study strategies, they must be helped to plan effective study strategies for achieving up to potential. Role of a teacher is pivotal in the entire teaching learning process. He/she should play an important role in identifying students who are poor in their studies and motivate them for adopting good study habits. Students should be appreciated in their classes for using good study techniques so that they may be an example for other students. They must be cognitively engaged by guiding them to make connections, elaborate, translate, organize and reorganize so that they can think and process deeply- greater the practice and processing stronger the learning. Students should be taught conditional knowledge about when, where and why to use various strategies. Thus teacher can play an important role in helping students to develop effective study and learning strategies.

\section{Conclusion}

Since study habits is found to be correlated with SES of students it is essential that learning institutions should play an important role in encouraging and institutionalizing parental, instructional, and peer mentoring programs to develop good study habits and positive learning attitudes among students. Study habits of students are teachable and learnable and hence the above mentioned suggestions can be helpful to improve the study habits of students.

\section{Acknowledgement}

The author acknowledges Prof C.P.S Chauhan, Ex-Dean, faculty of Social Sciences and former Chairman, Department of Education, Aligarh Muslim University, (A.M.U), Aligarh for his sagacious guidance and remarkable suggestions during the course of the work.

\section{Reference}

Aisha R, Kiran A and Malik NH (2002) Relationship of study habits with educational achievements. International Journal of Agriculture and Biology 4(3): 370-371.

Alam MM (2006) Academic achievement in relation to Socioeconomic status, anxiety level and achievement motivation: A comparative study of Muslim and nonMuslim school children of Uttar Pradesh. Indian Educational Abstracts 6(2): 42-43.

Anton AF and Angel B (2004) Socialized personality, scholastic aptitudes, study habits and Academic achievement. European Journal of Psychological Assessment, 20(3): 157-165. Retrieved April $13 \quad 2013$ from http://www.content.apa.org/journal/jpa/20/13/157.html.

Caldas SJ and Bankston CL III (1997) The effect of school population, socio- economic status on individual student's academic achievement. Journal of Educational Research 90: 269-277.

Crede M and Kuncel NR (2008) Study habits, skills, and attitudes: the third pillar supporting collegiate academic performance. Perspectives on Psychological Science 3: 425-453

Fielden K (2004) Evaluating Critical Reflection for Postgraduate Students in computing. Informing Science and Information Technology Education Joint Conference, 2005, Flagstaff, Arizona, retrieved April 17, 2013 from www.informingscience.org/proceedings/InSITE2005/I38 f36Field.pdf.

Graetz B (1995) Perspectives on socioeconomic status in Ainley J, Graetz B, Long M and Batten M. Socioeconomic Status and School Education. Canberra: Australian Government Publishing Service, 5-22. 
Hong E and ve Lee KH (2000) Preferred homework style and homework environment in high-versus low-achievement Chinese students. Educational Psychology 20(2)

Houtte MV (2004) Why boys achieve less at school than girls: the difference between boys' and girls' academic culture. Educational Studies 30(2).

Jeynes WH (2002) Examining the effects of Parental absence on the academic achievement of adolescents: the challenge of controlling for family income. Journal of Family and Economic Issues 23 (2).

Laxminarayanan TR et al. (2006) Achievers and non-achievers compared in study skills. Journal of Community Guidance and Research 23(3): 292-295.

Lidhoo ML and Khan MA (1990) Bright underachievers among the socially backward: Counselling and remedial measures. Indian Educational Review 25(1): 21-30.

Patel BV (1974) Study habit Inventory Scale: (SHI), manual Agra: National Psychological Corporation.

Perveen A (2011) Effect of counseling on the Need-achievement, study habits and academic achievement of under achievers. Ph.D Thesis, Dept. of Education, University of Kashmir retrieved April 5, 2014 from http://dspace.uok.edu.in

Pillai SK (2012) An empirical Study on study habits of X standard students in Nagarkovil District, Research Expo International Multidisciplinary Research Journal 2. Retrieved April 13, 2013 from researchjournals.in/documents/Sep2012/2325.pdf
Sarwar M et al. (2009) Study-orientation of high and low academic achievers at secondary level in Pakistan. Educational Research and Reviews 4(4): 204-207. Retrieved from http://www.academicjournals.org/ERR

Sharma M (2009) A study of secondary school student's achievement in science in relation to attitude towards multimedia and certain personal and institutional factors. Unpub Ph.D. Edu, AMU.

Sirin SR (2005) Socio-economic status and academic achievement: A Meta-analytic review of research. Review of Educational Research 75(3): 417-453. Retrieved from http://steinhardt.nyu.edu/scmsAdmin/media/users/lec321/ Sirin_Articles/Sirin_2005.pdf207

Sirohi V (2004) A study of under-achievement in relation to study habits and attitude. Journal of Indian Education 30(1): 1419.

Srivastava GP (1997) Socio-economic status scale (SESS), Urban manual Agra: National Psychological Corporation.

Sud and Sujata (2006) Academic performance in relation to selfhandicapping. Test anxiety and study habits of high school children. Psychology study 51(4): 304.

Suleman Q et al. (2012) Effects of parental socio-economic status on the academic achievement of secondary school students in district Karak (Pakistan), International Journal of Human Resource, retrieved April 24, 2014 from http://www.macrothink.org/journal/index.php/ijhrs/issue/ view/145

Tinklin T (2003) Gender Differences and High Attainment, British Educational Research Journal 29 (3). 